\title{
2020 Teacher Candidate Voter Turnout: Implications for K-12 and Higher Education
}

\author{
Hannah Jeffries ${ }^{* 1} \&$ William McCorkle ${ }^{1}$
}

* Corresponding author

E-mail: jeffrieshr@cofc.edu

1. College of Charleston

Department of Teacher Education

Charleston, South Carolina, United States

\section{Article Info}

Received: October 2, 2020

Revised: December 9, 2020

Accepted: December 10, 2020

\subsection{3/repam.2020.4}

\section{How to cite}

Jeffries, H. and McCorkle, W. (2020). 2020

Teacher Candidate Voter Turnout:

Implications for K-12 and Higher Education. Research in Educational Policy and Management, 2(2), 52-77.

https://doi.org/10.46303/repam.2020.4

\section{Copyright license}

This is an Open Access article distributed under the terms of the Creative Commons Attribution 4.0 International license (CC BY 4.0).

\begin{abstract}
This study centers on low youth voter (18-24) turnout nationally by examining a study of teacher candidates at a South Carolina public university. The study is useful to understanding the civic engagement of two important demographics: youth voters and future educators. As teacher candidates, the students tended to have weak civic education backgrounds and a lack of understanding of the inherently political nature of teaching. Paralleling national trends for youth, candidates showed low levels of voter turnout, a disconnect between accessing political information and making informed decisions, and a general cynicism towards electoral politics. The study was able to explore multiple important demographic differences in attitudes towards voting. The study also explored attitudes of practicing teachers towards civic engagement and the implications of these attitudes for $\mathrm{K}-12$ and higher education.

\section{KEYWORDS}

Civic engagement; civic education; teacher candidates; youth; voter turnout.
\end{abstract}




\section{INTRODUCTION}

This study took place following Joe Biden's strategic win of the 2020 South Carolina Democratic Primary. Especially notable in Biden's win was his previous losses to Senator Bernie Sanders-- a stronghold candidate with youth leading up to the South Carolina primary. During a controversial and polarized election year such as 2020 , this study looks at the intersections of politics and education for voter turnout.

Like many elections, the 2020 South Carolina primaries were in some ways decided not by who voted, but by who did not vote. While van Wagtendonk (2020) highlights that this election held a record breaking number of voters in the Democratic primary at 524,000, still a fairly small turnout compared to the 3.3 million registered voters in the state (South Carolina Votes, 2020). Arguably, low levels of South Carolina youth voter turnout (8\%) led to Biden's primary win, and therefore his subsequent Democratic Party presidential candidate nomination. This study also coincides with a significant transition in teacher activism and advocacy throughout the state. Though South Carolina lacks a teacher union, in 2018 an organization called SC for ED arose to advocate for changes in the education system, particularly better teacher pay, smaller class sizes, and more educational funding overall (Who We Are, n.d.). In May 2019 a large protest took place at the capital in which 10,000 South Carolina teachers advocated for education reform. Democratic candidates clearly believed in the electoral significance of their momentum; every single candidate in some way showed support for the teacher march. As the teachers marched they chanted, "We teach. We vote" (Lee, 2019). The question-- just like with the broader youth activism-- is whether this strong passion among a group of teachers for political change reflects the stance of teachers more broadly.

\section{Aims of Study}

The purpose of this study is to examine youth voting trends in an influential electoral state, South Carolina, during a controversial election year-- 2020--specifically during the primary season. Because most of the teacher candidates from this study recently graduated high school, the study simultaneously gauges K-12 civic education trends as well as youth generally (18-29). Specifically, the study explores political attitudes of teacher candidates-- a demographic with a profound influence on the future of youth voting. While the youth vote is consistently studied, teacher voting patterns remain minimally studied.

\section{Research Question}

What was the level of civic engagement among education students, particularly related to the 2020 primaries and the 2018 midterms and what were the reasons associated with more or less engagement? 


\section{LITERATURE REVIEW}

Public schools and state-mandated social studies curriculum encounter the conflicting desires between politics and education, order and critical thought; to both groom an obedient and patriotic citizenry as well as ensure that citizens actively question their government (Tyack \& Cuban, 1995). While public schools were originally created to build an educated populace active in our democratic society (Matto et. al, 2017), low voter turnout demonstrates that the education system's initial mission to create active citizens has not necessarily been successful.

\section{Teaching as a Political Act and Critical Pedagogy}

Many teachers do not see the teaching profession as a political act, but their roles as teachers inherently--even if not intentionally-- make them political (Nieto, 2006). Teachers are at the epicenter of creating change, and while amidst a hierarchy of standards and administration, they are the most uniquely positioned individual to substantiate engagement (Torney-Purta, 2002; Nieto, 2006.) Whereas some teachers might describe themselves as neutral, even 'apolitical', the relationships of power, privilege, politics, and education are so intertwined that even the most mundane decisions in a classroom are politically driven (Neito \& Bode, 1998).

Education and Equity. In teaching, even being 'apolitical' is in itself political. As Freire (1970/1992) states, "washing one's hands of the conflict between the powerful and the powerless means to side with the powerful, not to be neutral." Because education exists as a product maintained and structured by the dominant class, unless explicitly and consciously counteracted, education systems fuel the supremacy of the dominant class (Apple, 2013; Counts, 1932/1978; Nieto, 2006) and reinforce the gaps between racial, economic, and social groups. Critical education remains a crucial component in creating an education system that combats this, and promotes a democratic and forward-thinking society (Apple, 2013; Counts, 1932/1978; Delpit, 1998; Freire, 1970/1992; Nieto, 2006).

In low income and minority communities, education and oppression go hand in hand, and education often, 'exacerbate[s] rather than ease[s] social class and race inequalities" (Nieto, 2006). Teachers of low income and/or minority students are in a particularly relevant role in regard to the political ramifications, as the education systems for such students are a critical component of their future social and economic power; if the education system determines one's chances of higher education, future job, and therefore economic status, their schooling intimately relates to that power (Delpit, 1988).

When conscious of their effect and intentional in their countering of oppression, education systems have, Counts (1932/1978) argues, the possibility to restructure the social order. A proper critical education, he argues, bridges the world of social inequality and true democracy. This restructuring requires courage and boldness to teach and lead students to think critically and objectively. Teachers who chose to teach neutrally, and teach students to choose neutrality, also base their teaching off politics. "Education is not a neutral activity, it is intimately connected to multiple relations of exploitation, domination, and subordination...," Apple (2013) 
writes, "there is nothing neutral about what is being taught." Teaching students to be critical thinkers, to develop their opinions, and constructively argue, is an important tool in future citizens' civic engagement education. Only teaching textbook materials and memorization is equally a political decision.

Avoidance and neutrality as political. For teachers that go into the profession consciously or subconsciously with an apolitical stance, aiming for neutrality can be a confusing and unachievable obstacle that both deters the student and the teaching, "teachers might find themselves struggling with the issues of professional neutrality in a profession that is, at its core, already not neutral" (Dunn et. al, 2019). During controversial election years such as 2016, Dunn argues, teachers face the challenge of teaching the elections from an apolitical stance, and ultimately avoid it altogether. This avoidance of controversy is part of the null curriculum; or why students are not given the opportunity to learn. Milner (2017) explains the null as, "what is absent or not included in the curriculum can actually be immensely present in what students are learning...if students are not taught and expected to question, critically examine, and call out sexist language in books, they are learning something - that it may not be essential for them to engage in this work of critique and exposure."

When teachers avoid certain topics for fear of controversy, they are making an important decision to teach that things that are political are not necessary to examine and critique, and it is even undesirable to do so. To effectively teach, teachers must have a conscious commitment to teach civic education topics--even when controversial. Avoiding topics such as controversial elections is in itself a political decision. When going into election years, regardless of the year, teacher decisions from K-12 and in every subject are an important lens into youth voting culture and potential voting patterns.

\section{Civics Education}

Schools globally are the first and oftentimes most enduring place in which citizens are exposed to citizenship education and engagement, therefore, Torney-Puta (2002) argues, they are also charged with the responsibility of creating citizens engaged in their democracies. Effective civic educations are explicit, enduring and broad, and community and student-centered (Dunn et. al, 2019; Teachers' Views on Civic Education, N.D.; Torney-Purta, 2002).

Explicit. Teachers must be direct in their discussions of citizenship, voting, and the electoral process. In the IEA study, explicit discussions of the importance of voting--and teachers not just relying on students' inference-- were a 'significant predictor' in the likelihood of students' future voting habits (Torney-Puta, 2002).

When teaching social studies, more specific topics deemed controversial such as elections are often intentionally avoided. This was especially true during controversial election years such as 2016 (Dun et. al, 2019). This is potentially due to teacher fear of controversy and lack of support from their district and administration. A Southern Law and Poverty Center (SLPC) study found that around the 2016 elections, 50\% of teachers hesitated to teach about the election in class. Some principals told teachers to refrain from discussing or addressing the 
election completely (Southern Poverty Law Center, 2016). Only 38\% of social studies teachers believe they would get strong support from their district to teach about elections (All Together Now, 2013). In red states like South Carolina with weak teacher unionization--49th in the nation (Winkler, Schull, \& Zeehandelaar, 2012), and when teachers' politics tend to conflict with the general populations (teachers lean liberal and South Carolina residents lean conservative) their fears lead to them purposefully avoiding these controversial topics.

While teacher fears might be founded, explicitly addressing controversial topics is a critical and necessary part of being an educator (Dunn et. al, 2019). Explicitly discussing such topics is actually not about divisions, controversy, or partisanship-- as Dunn argues--but instead about the teacher's commitment to education and societal equity. To teach critically and for social justice, teachers must be aware of the political nature of their work and be explicit in their teaching of civics.

Enduring and Broad. Civics education should also start young, cross-disciplinary, and hands-on. While many American civics educations start later in schooling and are explicitly in social studies and civics courses, Torney-Puta (2002) argues that students are capable of understanding American civics earlier in their education, as well as in a more critical light.

Drawing Practical Connections. Civics education also applies to the abstract, complex, and reallife nature of democratic citizenship; extending from abstract constructs, to participatory politics and the intersection of this with social media. Youth and teacher candidates alike struggle with understanding the importance of voting in the context of other forms of democratic citizenship, and that voting does not exist within a bubble of participation. Studies of teacher candidates have shown that pre-service teachers' ideas of democracy are generally 'shallow' (Trent et. al., 2010) and that they see democracy in a very traditional framework (Carr, 2008) with voting as the core and most important part of active democratic citizenship (Vesperman, 2017). These views overlook the importance of democratic citizenship in small scale endeavors such as local elections and community engagement and teacher candidates do not necessarily draw parallels between democracy active citizenship in its fundamental forms (i.e. voting) and more abstract forms (i.e. community service) (Carr, 2008). However, with proper guidance, pre-service teachers have proven to have an 'evolution' in their idea of democratic citizenship (Vesperman, 2017).

Participating in democratic citizenship and politics has evolved in recent decades, through the advent of social media and the accessibility of news. Kahne et. al (2008) suggests the importance of participatory politics ${ }^{1}$ and the intersection of such policies with social media as accessible mediums for youth looking to evoke change, citing examples such as the \#blacklivesmatter movement that gained traction in 2014 and has continued to manifest in civic engagement from social media to real-life action in 2020 (Parker et. al, 2020). However, critical

\footnotetext{
${ }^{1}$ Participatory politics as defined by Kahne are "interactive, peer-based acts through which individuals and groups seek to exert both voice and influence on issues of public concern.
} 
to this influx of information via news media and social media engaging citizens productively is their ability to disseminate information. Therefore, an effective civics education must also address civic literacy ${ }^{2}$ and critical media literacy ${ }^{3}$; skills that many teachers and students alike lack. A study of Massachusetts teachers found that critical media literacy was the number one civic education skill teachers thought students need to learn in the future, yet that they also felt unprepared to teach it (Teachers' Views on Civic Education, N.D.). ${ }^{4}$

Community and student-centered. A community and student-centered classroom is also essential to building an effective civic education. Reiterating Friere, (1970) an International Association for the Evaluation of Educational Achievement (IEA) study of the civic engagement of youth across 28 countries found that students having a sense of a classroom community, home community, and culture of discussion engagement is important to ensuring future political engagement (Torney-Purta, 2002). In these community cultures, students are able to make their learning materials more meaningful, demonstrate a value to student opinions, and also demonstrate how to have respectful and productive discussions. These ideal studentcentered classrooms, however, are rare, as the study found; 90\% American students reported that they mainly learned about social studies from textbooks and worksheets and are much less likely to learn via more interactive civic education methods such as debates, discussions, etc. (Torney-Purta, 2002). This is especially true in schools with students from low socioeconomic backgrounds. Importantly, low socioeconomic status also often results in less student opportunities for discussion and participation; which is problematic because discussion and participation opportunities is an influential aspect of eventual civic participation (Torney-Purta, 2002).This is true across other voting deterrents such as such as civic knowledge and other school-related factors (Torney-Purta,2002).

Demographics and Cultures of Voting. Education levels often correlate with other demographics in regards to voter participation. Higher levels of education is the most substantial influence on civic activity (Hall, 2014; Flanagan \& Levine 2010). For many students education is often their first and potentially only experience to develop a relationship of trust with public institutions. A cynicism towards the electoral system can be especially strong for youth that have had bad experiences with education systems, as the problematic experiences with education led to a general distrust of public institutions (Torney-Porta et. al, 2004). ${ }^{5}$

\footnotetext{
2 "Civic Literacy": Proficient civic literacy is a trend in countries with high levels of voter turnout. High levels of civic literacy, and therefore turnout, are important in creating an egalitarian society as it allows both for representation of minority groups and more educated populations tend to trend towards more egalitarian policies (Milner, 2002).

${ }^{3}$ Critical Media Literacy: While some youth might feel under-informed, the new inundation of political information on the internet and social media might make others feel over-informed; but both lead to feelings of frustration as to what to do with information. Even professionals like teachers are often caught in the chaos of an overabundance of sources. Wineberg (2018) notes examples of teachers distributing materials in classes from dubious sources; something he argues is a result of teachers that lack the skill of vetting the overabundance of internet sources themselves.

${ }^{4}$ Main concerns for teachers were a lack of available and relevant materials and professional development.

${ }^{5}$ Comparing five countries, the same authors found that to build a high constituency of voters, the government must first build a relationship of trust with young people through positive relationships with their experience in public institutions such as schools.
} 
Therefore a positive relationship with one's education is influential in the likelihood of voter participation. ${ }^{6}$ Because education levels and socioeconomic status often go hand-in-hand, nonminorities are often more civically engaged than other demographics, and family cultures of voting also exist generationally and by education level. The political involvement of young adults' parents is also highly influential, and parental education is the single most influential indicator of a young adults' future voting (Flanagan et. al, 2010). Students from low-income and low literacy backgrounds are less likely to engage civically and vote (Torney-Purta, 2002). This may be a reason behind less of a focus on real structural reforms related to issues of poverty and injustice. There is also a divide based on gender; females are also more likely to vote (Syverston et al., 2011; US Census Bureau,2017).

In-service Training. Teachers recognize the importance of in-service training and resources. Teachers note that civics courses are hard to teach, and that they struggle with teaching local (vs. federal) civics courses due to less available material. A study of Massachusetts teachers found that the pedagogy for civics is most effective when it is across disciplines, utilizes alternative practices such as project-based learning, is student-driven, and incorporates members of the community (Teachers' Views on Civic Education, N.D.).This was also found to be true in teacher education. Trent (2008) advocates for teacher education departments to demonstrate and model the ideal student-centered classroom.

Torney-Porta, Barber, and Richardson (2005) notethat of all aspects of building an effective civics education, teacher opportunities for professional development are most influential on student future civic knowledge. Teachers with professional development opportunities alone are the most likely to teach students that subsequently feel capable of casting an informed vote.

Educator Cynicism. While educators trend Democratic, ${ }^{7}$ they are cynical towards both parties. An Education Week survey found that for their handling of K-12 policy, $70 \%$ of educators give Republicans a "D", 45\% percent give Democrats a "D" or " $F$ ", and only 1 percent of respondents gave an " $A$ " to either party. $67 \%$ also had an unfavorable opinion of Trump, and 72\% had an unfavorable opinion of Secretary of Education Betsy Devos (Klein, 2017).

\section{American Civics Education and Low Youth Voter Turnout}

Nationally, data consistently reports lower rates of youth voter (17-29) ${ }^{8}$ turnout than that of other age groups. In 2016, $60 \%$ of the voting-age American population voted in the presidential elections, while only $46 \%$ of youth voted (US Census Bureau, 2017). There are several arguments on why the youth don't turn out in high volumes to vote.

\footnotetext{
${ }^{6}$ Youth with college plans are more trustful of government institutions, four times more likely to intend to vote than non-college-bound individuals, and have a 75\%+ higher odds of engaging in community service (Syverston et al., 2011). ${ }^{7}$ The majority of educators voted for Clinton (50\%) in 2016 vs. Trump (29\%) (Klein, 2017).

${ }^{8} 17$-year-olds that are eligible to vote in the general election are allowed to vote in some states' primaries.
} 
Logistics and Cynicism. The most concrete culprit is logistical issues. Issues include core aspects such as knowing how (the voting process) and having the actual ability to make it to the polls. ${ }^{9},{ }^{10}$ There is also a general cynicism of youth towards the electoral process and elected officials (Torney-Porta, Richardson, \& Porta, 2004). Youth in particular do not have faith in elected officials to see change; thirty-year trends found that only a minority of youth believe that candidates are honest and can be trusted (Syverston, et al. 2011). While youth with negative educational experiences are the most cynical towards public institutions-- as previously noted--youth across demographic backgrounds are cynical towards elected officials.

While youth might be skeptical towards electoral candidates and the electoral process, their cynicism is not that same as an indifference to the importance of voting; only $20 \%$ of Texas youth agreed in the popular rhetoric that their vote 'doesn't matter.' (Texas Media \& Society Survey, 2018) and that between $80 \%$ and $90 \%$ of students in the United States and most of the other countries thought that voting was "very important" (Torney-Purta, 2002).

Not 'informed enough'. Two surveys found not being 'informed enough' to be a trend; in one, $17 \%$ of youth did not feel informed enough to vote (Engaging a Broader Youth Electorate,, 2018), and in another $16 \%$ of respondents across age groups did not believe that they are informed enough to cast an informed vote (Texas Media and Society Survey, 2018). The IEA study that found students to believe that voting is very important (Torney-Purta, 2002) also found that only $58 \%$ of these students believed it was important or very important for citizens to participate in political discussions, demonstrating a gap in understanding of civic engagement and voting not existing in a microcosm, and being informed enough to vote is something that requires extracurricular activities and general scaffolding.

Alternative Civic Engagement. In the United States, students have very positive attitudes towards conventional citizenship (i.e patriotism and voting). However, their understanding of more abstract forms of democratic citizenship and engagement (i.e. volunteering) are lacking, even if they participate in them. Students do not understand the interconnectedness of civic engagement acts such as voting, and activities such as voting, as both being important civic acts.

While youth are becoming less and less likely to participate in traditional politics, they are more likely to participate civically in other ways; such as volunteering in their communities or participating in a protest (Syverston et al., 2011). American youth that participated in a protest tripled from 2016-2018 (Five Takeaways,, 2018) and youth globally also seems to be trending towards more local engagement and activism (Torney-Purta, 2002). This disconnect between youth voting continuing to be low, but alternative civic engagement rising could be a result of conventional citizenship education that emphasizes abstract ideals of citizenship but

\footnotetext{
${ }^{9}$ More complex logistical issues also exist for youth voters; such as not having permanent addresses and/or living between two states (Scott, 2020). This problem has become especially apparent during times such as COVID-19 epidemic, when millions of students have been displaced out of state from their colleges to their parents' homes, oftentimes across state borders, complicating their state voting residency (Morrin, 2020).

${ }^{10}$ This commonly cited culprit for lack of youth turnout was combatted in 2018 by Apps such as Uber and Lyft offering free rides to the polls.
} 
does not actually connect it to action in a school-based or home-based community. TorneyPurta (2002) argues that schools must use a less traditional approach, and schools should be connecting the organizations and movements that do currently draw young people to the traditional civics education.

The Evolving Social Media Influence. CIRCLE (2018) research highlights that social media is not just a source of information and awareness, but a gateway to civic engagement for youth that are otherwise in 'civic deserts.' Social media became more influential for reaching out to youth than traditional means; more youth heard about campaigns (28\%) through social media than through traditional campaign outreach (13\%). And during $2018,47 \%$ of youth heard about the elections through common social media ${ }^{11}$ (Understanding Youth Attitudes and Beliefs, 2018), with Facebook being the most popular. In 2020, social media was especially influential in the social media youth activism following the death of George Floyd and subsequent civic engagement such as sharing information on social media (53\% shared content on racial inequality), protesting (13\%), calling legislatures, having conversations with family and friends, and contributing money to organizations.

These participatory politics, as Kahne (2020) argued, are becoming an increasingly important aspect of youth engagement. Youth that were exposed to electoral information via social media were more likely to vote; $55 \%$ of youth exposed to politics via social media voted in 2016 , versus $39 \%$ of youth that did not. Social media also has the capability of transcending otherwise common demographic boundaries for reaching youth: socioeconomic backgrounds, education level, location, race, and gender (Parker et. al, 2020).

Political Polarization, Social and News Media, and Civic Engagement. While the abundance of news information has allowed for unprecedented access to politics, this access has also brought challenges to modern citizens. Television viewing is negatively associated with civic participation and trust in citizens (Putnam,1995). This distrust of politics and general cynicism bred by the news media has led citizens to be less interested in participating in their democracy. A 2019 Pew Research Center survey put it simply when stating that two-thirds of Americans are "worn out" by the amount of news they come in touch with on regularly, that 8 out of 10 Americans believe that the US has become more polarized in recent years, and that half of adults agreed that talking about politics with people from the other side of the spectrum is "stressful" (Anderson \& Auxier, 2020). These findings demonstrate a general nature of political polarization in the US and a generally exhaustion boarding on apathy with exploring politics and working towards finding common ground to progress together in a democracy.

\section{DESIGN AND METHODS}

This study was based in a descriptive design which is "likely to reveal a chain or a network of causes and effects, connecting influencing factors with the criterion" (Blessing, Chakrabarti, \&

\footnotetext{
${ }^{11}$ This includes Facebook, Instagram, Snapchat, and Twitter.
} 
Wallace, 1998, p. 45) using a mixed-methods concurrent triangulation approach (Terell, 2012) that incorporated a broad range of qualitative and quantitative questions that were collected simultaneously. The data was analyzed from this broader descriptive perspective that "involves identification of attributes of a particular phenomenon based on an observational basis" (Williams, 2007, p. 66). The quantitative data examined correlations where relationships between variables were examined without seeking to claim causation (Johnson, 2001; Thompson et al., 2005). The qualitative data was analyzed with a type of interpretive description design approach (Thorne et al., 2004) with the goal of " a coherent conceptual description that taps thematic patterns and commonalities believed to characterize the phenomenon that is being studied and also accounts for the inevitable individual variations within them" (p. 4). In the case of youth voting, what were some of the larger themes that arose regarding youth engagement with additional focus on the unique aspects of different teacher candidates' experiences.

\section{Participants}

The majority of the participants $(n=52)$ were teacher education students. The participants were specializing in a broad range of grade levels (elementary-secondary) and subjects (all core disciplines). The study was composed of majority female respondents (78\%). Students were almost split evenly politically: $42 \%$ leaned Democrat, $18 \%$ reported being moderate, and $40 \%$ leaned Republican.

Students were not asked their racial backgrounds given the small number of minority students in the classes and the desire to maintain anonymity. Similarly, the age of the participants were not gathered for a similar reason given the small number of non-traditional students in the class. However, for descriptive purposes, approximately $80 \%$ of the students in the classes were white with several black and Hispanic students. There were approximately 4 students who were non-traditional and over the age of 25. Research shows that youth such as the type in our study--ones with higher levels of education, non-minority, and female--are the most likely to vote (US Census Bureau, 2017). The university at which the study took place is predominantly white (78\%) and female (68\%).

\section{Instrument}

The instrument used for this study was a a questionnaire that had both quantitative and qualitative questions. The questions from the survey were self-generated by the researchers and were based specifically on the issues surrounding voter turnout and civic engagement within the 2020 U.S. primary election season. The quantitative questions were made up of both categorical and Likert-type scale questions to understand the diversity and variance between the participants. 


\section{Data Collection}

The study was distributed in an entry-level and an advanced-level teacher education class in a university E-learning classroom in April of 2020. The advanced level course was an elementary and middle grades social studies methods course. The students were given time during the class to complete the survey. However, participation was voluntary and was anonymous. However, the majority of the students completed the survey. All the data was collected through Qualtrics. Data Analysis

The data that was collected in Qualtrics and then both the quantitative and qualitative data was analyzed. The qualitative data in particular was analyzed using the interpretive description design approach (Thorne et al., 2004) where broad patterns were inferred while also leaving space for unique and divergent perspectives from the participants. The quantitative data was primarily descriptive in nature to understand the broader trends amongst the participants. However, there were limited inferential analyses conducted using both a correlation analysis and a one-way ANOVA analysis to understand the relationship between civic engagement/political engagement and media practices.

\section{FINDINGS}

Both the quantitative and qualitative data revealed numerous themes to answer the research question in regard to larger trends regarding civic engagement and the reasons for turnout or absenteeism among young voters.

\section{Varying Voting Trends}

In contextualizing the results, it is important to place the information into the overall trends of youth nation and statewide. While youth participants in the study in some elections mirrored national and statewide trends, in others they did not. Students were both asked about how they voted in the 2016 and 2018 general elections and the 2020 primaries. Students in the 2018 elections mirrored national trends: $32 \%$ of the surveyed students reported voting compared to the national average of $28 \%$, refer to Table 1 (2018 Election Center, n.d.) ${ }^{12}$. However, our students had a much lower turnout compared to the national average in 2016 , while $46 \%$ youth voted nationwide only $32 \%$ of eligible surveyed students did (US Census Bureau, 2017) ${ }^{13}$. Strikingly, surveyed students turned out in much higher numbers than the state average for the 2020 open Democratic primary; $26 \%$ of students reported voting whereas statewide only $8 \%$ of eligible youth voted, see Table $2^{14}$ (Youth Make Up 1 in 9 South Carolina Voters, 2020).

\footnotetext{
${ }^{12}$ While South Carolina has high levels of Republican-leaning youth, the primaries are open; therefore, youth from both parties are eligible to vote.

${ }^{13}$ Only $38 \%$ students surveyed were eligible to vote in the 2016 elections (due to age restrictions), so they were the only one included in this figure.

${ }^{14}$ While $34 \%$ of our participants voted total, $8 \%$ of those voted out of state. Because SC is an open primary and other states are not, the data from out-of-state participants cannot be included legitimately.
} 
TABLE 1: Voting Data for Youth (18-29)

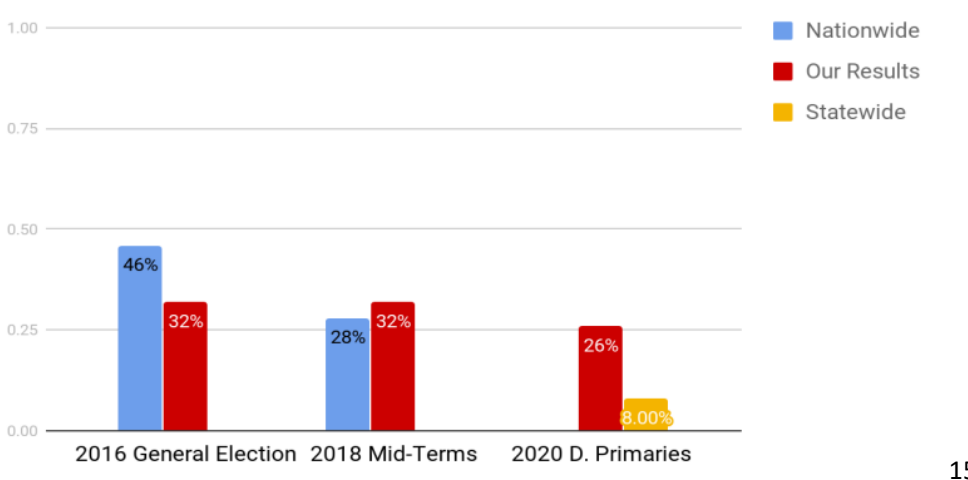

While the data is not consistent in many ways, it is consistent in demonstrating an overall low turnout (below 50\%) for youth nationwide and statewide across elections. More importantly, it shows that in no election did the majority of surveyed students vote, therefore proving there is a low voter turnout in this surveyed demographic. After conclusively determining that the surveyed candidates turned out in low numbers to vote, we studied the quantitative and qualitative data to examine potential reasons for this.

\section{Reasons for Not Voting}

After analyzing the broader civic engagement, we sought to analyze some of the reasons for greater or lesser civic engagement. The most common theme-- which led substantially--for not voting was not feeling "informed enough" (28\%). This was trailed by 2 ) logistical issues (14\%), 3) a strong cynicism towards both candidates as 'being bad' (17\%), 4) and students noting that they are 'not political' (14\%). Students were also notably deterred by the 'polarization' of political leaders and parties.

Not being "informed enough." We also asked students to rank the reasons they did not vote if they abstained from voting in the 2020 primary. Aligning with the studies mentioned, not feeling "informed enough' was a common trend (28\%), and in our study the most commonplace reason for not voting. This lack of informedness was more based in skills such accessing information and making an informed decision than logistics such as how to register. See Table 2.

As one student wrote: "I did not do enough research on the candidates to feel like I should have voted. I would like to be educated before I vote," and another stated "I don't vote because] I never feel informed enough." This lack of knowledge was related to a fearfulness and lack of confidence in regard to voting, As a student wrote "I did not vote because I thought that I would pick the wrong person to run for the 2020 election." Another stated, "I did not vote. I did not feel informed enough to make that big of a decision." One student noted that the current

\footnotetext{
${ }^{15}$ Data was collected through Qualtrics. The graphs were also created using this program.
} 
political climate seemed "moderate" but that also noted that "I would like to know more about politics."

Students also touched on their lack of information on electoral candidates stemming from not having enough exposure to traditional sources of political media such as news outlets: As one student stated "I do not feel like I had enough information to vote the way I would have liked because I do not watch the news as much as I like." While not being 'informed enough' was based more in abstract decision making skills than concrete logistical skills, one student did not know how to register, and they suggested it was something that they missed out on in school. They wrote, "I do not know how. I wish they talked more about voting in school."

TABLE 2: Qualitative Themes: Q27-If you did not vote, what would you describe as your reasons for not doing so?
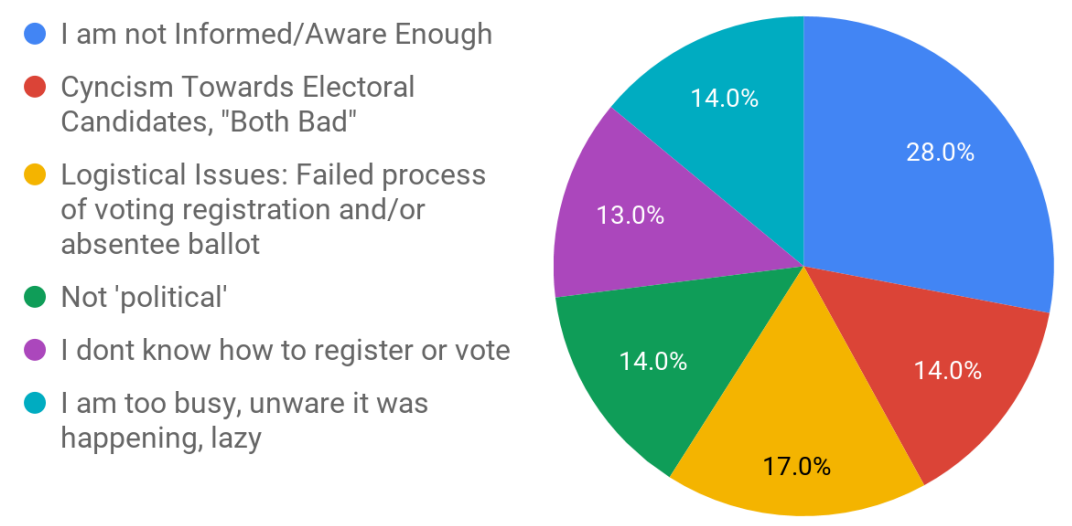

Logistical constraints. While Table 4 shows logistical constraints as the second most common reason for students not voting in their qualitative answers, logistics were not a common theme in their written, qualitative data and therefore logistical constraints as a main predictor in low turnout is not an especially strong factor in this study. It may be that the logistical constraints that eliminated voting for students were more based in missed deadlines and lack of prioritization than real impediments to voting.

For example, student responses were such as: "I was too late because when my dad had mailed me the information to vote, the day had already passed." Another stated, "I wasn't aware of when it was and didn't feel informed enough, so I simply didn't." Another student wrote that "I had to work during the 2020 Primary at my job and for the 2018 election I was out of town on vacation."

Registration Across State Lines: While 6\% (2/33) students that did not vote in the 2020 reported it was because they did not know how to register, this was not a common theme, and the majority of students were in fact registered. Going to the university across state lines-another logistical constraint--should not have had a strong impact on turnout as $76 \%$ of students were South Carolina residents. It should be noted that some of the students registered as part of a previous class at the university, so this could have slightly increased this percentage compared to the general population. 
Students were more likely to state logistics as a hypothetical reason than other youth did not to vote. See Table 3. In response to the question of why the youth vote is low, they stated "They do not know how," "I definitely believe not knowing how to register plays a huge role in this", "Voting registration can be a complicated process, as well as getting an absentee ballot. Both are much more complicated than necessary."

TABLE 3: Qualitative Themes: Q28- What do you think are some of the reasons that OTHER YOUTH dont vote?
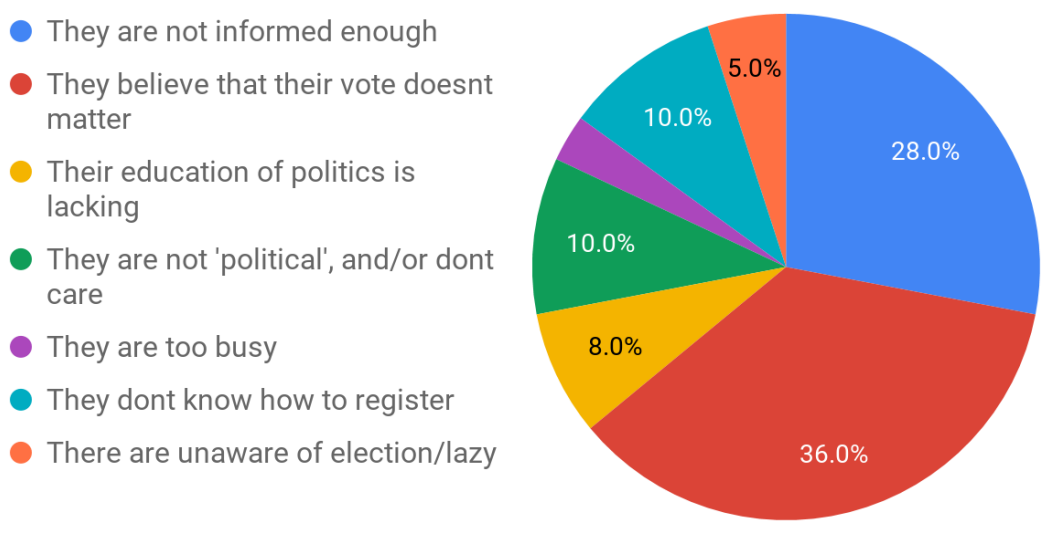

While logistical issues are often portrayed by many as the primary reason for low voter turnout, at least in this study, these issues did not seem to be the top priority. A general indifference to the voting process underlined the logistical reasons for not voting, and in their qualitative answers for not voting, logistical issues were not a trend. This calls into question whether these reasons are the actual reason that students did not vote, or whether they were a surface issue based in more problematic and abstract reasons for their abstention. Either way, students citing these issues did not seem to have an explicit desire to vote or feelings that it was part of their civic duty.

Cynicism Towards Electoral Leaders but not the Electoral System. The third most commonly cited reason for not voting was a cynicism towards elected leaders, (14\%) simplified as the notion that, "both candidates are bad". Refer again to Table 2. Students reported: "[I] did not believe in [political candidates] enough to vote for either", Because both candidates were bad. I saw very little difference between them, just different packaging. I felt my ability to not vote was exercising my right to vote," and, "I've never voted because I don't have confidence in any of our politicians in Washington..." A candidate distanced themselves from political leaders while simultaneously discussing civic engagement, "I've never voted because I don't have confidence in any of our politicians in Washington. I prefer to be more involved at our local level."

Political polarization also seemed to have a very strong effect on students' opinions on politics. Students wrote, "I also think that politics has gotten really polarized, and that there needs to be more middle ground, "[We live in] a very divided country and society," "The longer 
I pay attention to politics the more I see that it is a battle between two groups.." "It is too split," and, "[The US] is way too divided."

Students Lack of Civic Knowledge. Students also lacked a basic knowledge of current politics. We measured this by asking about their knowledge of elected officials. Only $50 \%$ knew the current US Secretary of Education (Betsy Devos) and only 44\% knew who the South Carolina senators are. Given the career of the students and their location in South Carolina, both areas were relevant. Though not statistically significant largely due to the sample size, there appeared to be a pattern with knowledge and voting with $33 \%$ of students who knew both items having voted in the 2018 midterms compared to only $20 \%$ who knew either one or neither of the items.

Apathy to Politics. As noted, teacher candidates are apathetic to electoral candidates and political polarization, to the extent of avoiding politics all together. Teachers distance themselves from politics, with $14 \%$ stating that they are altogether "not political," a troubling trend when teaching is in itself arguably a political act. They wrote things such as, "I am not a political person" and "I don't really care about politics." One student summarized their feelings as, "Politics honestly stress me out." However, they continued with, "I'm not saying politics are bad just how people interact with it." Candidates noted they were not political because it is controversial. "I have my own personal political beliefs; however I also stay away from politics because I find it problematic and controversial," "I don't know what is going on really in politics and it seems like everyone up there is arguing," and, "People are afraid to talk about [politics] or have different opinions than other people."

\section{Broader Societal Trends}

In addition to the reasons that led to some students choosing not to engage in civic action, there was also an exploration of some of the broader social context of civic engagement including what students saw as the reason that other do note vote, voting patterns among their friends and family, and the role of media and social media.

Reasons Other Youth Don't Vote. When asked why other youth do not vote, the majority of respondents (36\%) reiterated the stereotypical rhetoric of youth not voting because their vote 'doesn't matter.' However, this rhetoric was challenged by these groups themselves; while this youth are cynical towards political parties and leaders, and to an extent the American political system, they are not apathetic to voting as a whole. 92\% (1/52) agreed that their personal vote does to some extent society, and only one student $(n=52)$ cited this as the reason that they did not vote. With the rhetoric of youth not believing their vote matters, ideas from youth on lack of youth turnout are more inclined to stereotypical narratives than fact. Refer again to Table 3.

In hypothesizing reasons that other youth do not vote, students again reiterated youth not being 'informed enough'. They wrote: "[youth don't vote because of] a lack of education about politics, people don't feel like they know enough to make an informed decision," "because 
the youth is not informed enough," and "a lot of young voters are unsure about what party and beliefs they align with, especially if their beliefs contradict their parents."

It is intriguing that the participants were more likely to see their peers' reasons for not voting as due to busyness or laziness with less being willing to state that as their reason for not voting. Students also noted that political apathy led to youth, in their opinions, not doing the research necessary to feel informed enough to vote, "I believe that there is this notion that our vote does not matter, so many people do not care to do the research needed to vote responsibly" and, "I feel as though some of the youth are lazy or are not educated on the people running in the election and feel like it is not important to vote. they do not understand how much voting can change the world we live in."

Voting among Friends and Family: The culture of voting amongst age groups had a strong divide; the majority of students (14/52) reported that $0-15 \%$ of their closest friends vote, whereas that $74 \%$ of all students reported their parent or immediate family voted. Civic engagement is also lacking broadly; $34 \%$ percent reported their friends' level of civic engagement to be either "weak" or "very weak." See Tables 4-5.

Table 4: Percentage of close friends who vote

Q20 - What percentage of your closest friends vote?

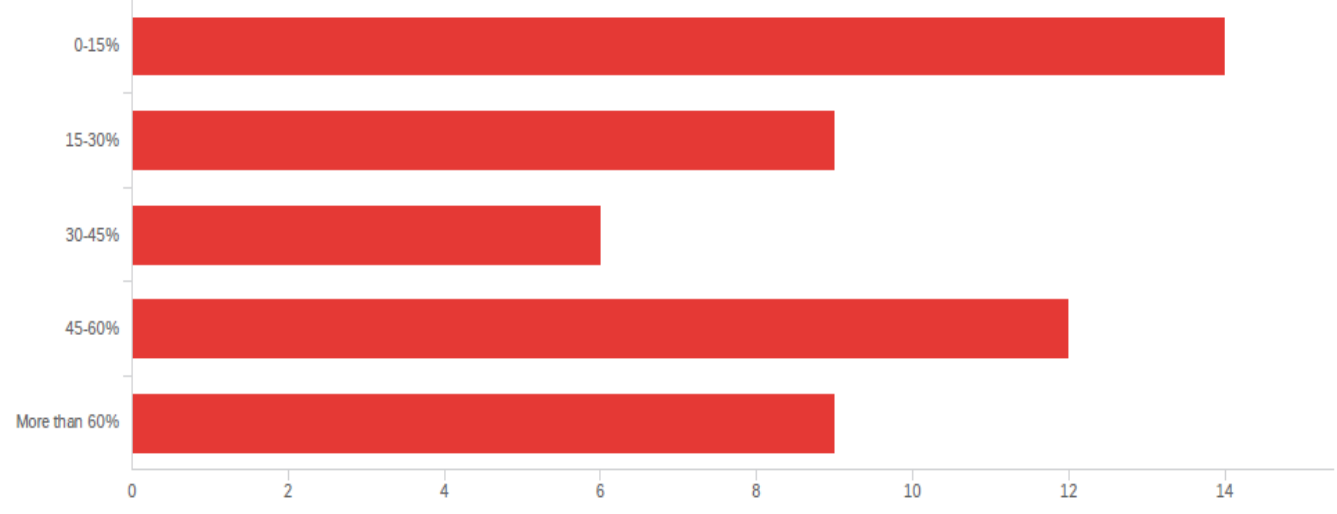

Table 5: Voting among parents and immediate family

Q24 - Did your parents or immediate family vote? 
The age divides in the voting patterns of these students and their friends as compared to their parents and immediate family is striking, and while older generations being more inclined to vote is not a finding, this data is striking as high levels of parental voting are part of generational voting trends that often positively influence future voting (Flanagan et. al, 2010). $70 \%$ of students also reported their professors encouraging them to vote during the 2020 primaries. This data proves that these students come from cultures of voting, even if they themselves are not voting.

Social Media and News Consumption. Social media clearly plays a strong role in students' lives. While $75 \%$ of students reported less than 2 hours a week watching, listening, or reading the news, $57 \%$ students reported spending more than 2 hours a day on social media. ${ }^{16}$ Students that spent a median amount of time on both social media and news consumption were the most likely to vote; suggesting the importance of a balance of the two as both a way of being informed and substantiating that social media is a gateway to engagement. While students might not be getting their news from the traditional outlets that older generations such as their parents are getting theirs (i.e. evening news vs. Instagram), they are still very much accessing news information. Rates of voting tended towards median amounts of news information; students that exceeded 2 hours a week of news were not more likely to vote than their peers. However, students with high levels of social media use were equally as likely to vote as those with median or low social media usage.

We employed an inferential quantitative analysis to see if there was a relationship between the amount of news viewed, the amount of time spent on social media, and the probability of voting. We used the metric of voting in the 2018 midterm elections and/or the 2019 local elections since this would have covered those who may not have voted in the 2020 primaries due to their political affiliation or may have not been old enough to vote in the 2016 elections. The Spearman rho showed that there was a significant correlation of .308 $(p=.031)$ between more hours of news consumed a week and voting in the 2018 election. There were no significant results between the amount of time spent on social media and the probability of voting. Though it was not statistically significant, students who voted in the 2018/2019 election were more likely to hold liberal political ideologies. Based on a scale with 1 being very conservative and 7 being very liberal, those who voted had a mean of $4.83(S D=1.7)$ compared to a mean of $4.14(S D=1.5)$ among those who did not vote.

An ANOVA analysis revealed that there was no statically significant relationship between the most used form of social media used and level of voting. However, interestingly, the highest levels were among Snapchat followed by Facebook, Instagram, and then Tik-Tok. There were only 2 who said that Twitter was their most used form of social media. This is an area where a

\footnotetext{
${ }^{16}$ The top social media platforms were Instagram then Snapchat, trailed by Facebook, and eventually TikTok and Twitter.
} 
larger sample may be of assistance as the link between social media and civic engagement is studied.

\section{DISCUSSION}

As referenced in the findings section, the participants in our study voted at significantly higher rates than other youth in the state in the context of the 2020 primary (Youth Make Up 1 in 9 South Carolina Voters, 2020). They also voted at higher than the national average for youth in the 2018 midterms (2018 Election Center, n.d). However, in our perspective, these numbers were still lower than they should have been.

As a demographic- predominantly white, educated, college females, from families of cultures of voting- these candidates should have comparatively high levels of voter turnout. However, in many cases they seemed to effectively distance themselves from politics. There were many reasons for those who chose not to engage in civic actions. Common sentiments of not being 'informed enough' to cast a vote are a troubling trend in this study and reiterate the findings in the Texas Media and Society Survey (2018) study. This is especially troubling with our demographics and demonstrates a possible failure of these students' K-12 civics education and raises questions for the future of our democracy. These concerns of the lackluster youth engagement reflect those of Winthrop (2020) who calls for greater civics education.

Jansen (2011) contends that for greater student civic engagement, there needs to be a more student-centered approach that has as strong focus on civics education. As our data suggests, this focus seems to be lacking as some students do not feel informed enough to vote, state that they are not political, or as one student remarked-are scared of making poor decisions. The lack of confidence and even apathy may also be due to an educational approach that does not allow students to truly personalize the civic realities for themselves. It is also possible that this lack of knowledge may lead to the overly broad cynicism that some participants in the study demonstrated.

Bittman and Russell (2017) argue that greater engagement with current events helps to raise student civic awareness. This relates strongly to the results pertaining to the reasons students saw for other youth not voting. One of the main culprits was the idea that their vote simply did not matter. This also relates to the $36 \%$ of those who did not vote saying that it was because they are not aware/lazy. This paired with the fact of many students spending a great deal of time on social media, perhaps in ways that are not beneficial academically or socially, compounds the fact that many youth and even future educators are not truly engaged in the issues that are pertinent to the world around them and thus are more likely to simply not engage.

\section{Implications}

There are numerous implications to draw from this study that relate to both educators and teacher educators more specifically. There is special relevance for those that are involved with 
social studies education. Below are just a few of the possible implications that this research has for educators.

\section{Critical Digital Literacy}

While lack of informedness of concrete logistical issues was present, students were more likely to not vote due to a lacking ability to research candidates and a foundation in critical digital literacy skills. An explicit education in critical media literacy is necessary for students to be able to discern credible information as well as fill in gaps in their information. Youth such as these candidates have unprecedented access to news media as well as constant exposure to social media platforms are that increasingly evolving to be more political. However, they still do not feel they have the tools to make an informed decision. This brings into question: are students aware that they are poor at disseminating the legitimacy of sensationalism and biased news? Does the inundation of political information help or hinder them in their confidence towards the voting process?

\section{Explicit Connections}

Explicit connections from informedness to eventual action are critical. Youth are being exposed to social issues outside of school settings through social media and news media. Some are also using this exposure to engage in the rise in participatory politics (i.e. sharing on social media, signing petitions, attending protests, and volunteering) but this does not necessarily translate into being active in civic engagement, or into making change effectively via voting. Small acts of civil engagement such as sharing posts on social media have potential to be gateways to actual engagement such as voting. Teachers should use small acts of engagement such as this to make explicit connections to this as an act that is parallel to more traditional acts of engagement such as voting.

Teacher educators must recognize the importance of teaching civic engagement through new spaces such as social media; a medium that has potential to engage communities, encourage local activism, recognize opinions other than one's own, and bridge otherwise rigid demographic backgrounds. Building classroom connections to local news media and positive news stories that demonstrate local connections to politics that are positive, tangible, and not polarized, is also a way of engaging students that has not been explored.

\section{Candidate Political Views, Polarization, and Distancing}

While youth apathy to voting--i.e. Don't vote because their vote 'doesn't matter'-- was not present in this study, there is an apathy towards the electoral system, elected officials, American current events, and sensationalized news media. Inundations of national news media and polarization has created a negative association with politics for students, and has created a climate of teachers and teacher candidates effectively distancing themselves from politics. While social media and news media acts a gateway to civic engagement, exposure to political polarization might also act as a deterrent for some. The apathy of the exposure to polarization 
breeds in students, for example, "politics honestly stresses me out, I'm not saying politics are bad just how people interact with it," reinforces the importance of a civic education teaching skills that can lead to constructive debate and critical thinking skills.

While teacher fears of controversy might be founded, explicitly addressing controversial topics is a critical and necessary part of being an educator (Dunn et. al, 2019). Explicitly discussing such topics is actually not about divisions, controversy, or partisanship-- as Dunn argues--but instead about the teacher's commitment to education and societal equity. To teach critically and for social justice, teachers must be aware of the political nature of their work and be explicit in their teaching of civics.

Teacher attempts to distance themselves from traditional politics in their classroom will be a tricky path for teachers, especially in controversial election years or low income schools. In addition to a distaste for abstract politics, there was an avoidance for traditional politics as well (i.e not knowing the Secretary of Education or SC state senators). Candidates not knowing figures such as the Department of Education and local leaders are problematic and question how much concrete change they can effect on the inherent way in which education functions systematically.

\section{Avoidance of controversy implications}

Educators that avoid political topics for fear of controversy rob students of the many important skills that topics such as elections can teach such as constructive debate, research skills, and how to come into their own politically; a great tool in minimizing polarization. This attitude of teachers towards avoiding controversy is problematic in school systems, as it essentially teaches students to avoid controversy in their personal lives, making it part of the null curriculum. Continuing these patterns of avoiding politics and elections in schools demonstrates to students that--like talking about politics and elections-- voting as well is not necessary. This is especially problematic of teachers in low-income schools where their work as teachers is especially influential in promoting democracy and restructuring the social order.

Candidates' very traditional views of politics and democracy are also an interesting aspect of their hesitance to engage politically, and because these teacher candidates see politics in a very traditional light, incorporating civic engagement education into their cross-disciplinary and grade level classrooms will be difficult. Their concrete understandings of politics and teaching underscore their ability to understand that as teacher candidates they are inherently 'political'. And while teachers may have good reasons for not wanting to be political-- such as working in non-union education states and/or a lack of confidence in their own civics knowledge-- avoiding controversy in the classroom perpetuates the deterrence to politics of their own students in the future.

Students must also be aware of the potential for change that is possible through their civic engagement; which can look many different ways, from voting to creating social media content. Civic education is one that in many ways takes place outside of the traditional school 
setting; on the internet and social media, in parks with statues, and on sidewalks. It is important for civics education for both K-12 to preservice teachers to understand the complex ways in which citizens are influenced by their democratic government in their day-to-day life (beyond voting and traditional civic engagement) and how through this they can facilitate change at the local and potentially larger level.

It is also important to note is that students as young as elementary school begin learning civic engagement and democratic ideas. Starting at the elementary level, the National Council on Social Studies recommends service-learning projects, extracurricular activities, class discussions and debates, role plays and simulations, and home-school connections (LevineGoldberg, 2009). The local community is also critical. In these community cultures, students are able to make their learning materials more meaningful, demonstrate a value to student opinions, and also demonstrate how to have respectful and productive discussions.

\section{Limitations and Future Study}

This study contains notable limitations. Critical to the South Carolina population, the African American community was underrepresented due to the small percentage of African Americans involved at this university. The students recently graduating high school productively allowed us to see trends of students in their late teens and early twenties. This however, might not be representative of the views or patterns of youth overall who experience greater political transformation at this age. Future studies could look closer at teacher candidates' civic engagement in aspects other than voting, their understanding of foundational civics and the intersection of this and their voting patterns, and their critical digital literacy skills.

\section{CONCLUSION}

Elections and civic engagement do not exist in a microcosm. Their successes and failures are not easily defined by a single concrete logistic but instead a myriad of abstract influences. While this study is just a glimpse into the voting cultures of youth nationally, it is important as it examines a small and neglected demographic of influential youth and civil servants. The situation we find ourselves in today--of low youth voter turnout, political polarization, and a general mistrust of government and political apathy--could very well be the product of an education system that taught teachers and students alike to avoid explicitly incorporating politics when teaching due to fear of conflict.

In a volatile voting year such as 2020, teachers and teacher educators may have more of a stake in youth voter turnout than they realize. In creating an ultimately egalitarian society, it is crucial that teachers in these roles understand the inherently political nature of their work in either progression and restructuring the social order or regression and maintaining the status quo. Teacher candidates' low voter turnout, their attitudes towards politics, and their general hesitancy towards politics and voting call the effectiveness of their civics education as well as their future power in creating effective citizens into question. While the first step is in building 
awareness, finding solutions remains less simple. Much like the reasons for youth not voting are more complicated than traditional simplistic rhetoric, so is finding solutions for increasing youth turnout. Similarly, low levels of teacher turnout signals trends of continued low turnout throughout future generations.

Civic education and engagement education does not have to be dry, traditional, or simply take place in a classroom. It is not a passive discipline but instead an active study that has the power to engage students from many demographic backgrounds in many alternative learning environments. Learning civics can (and should) be abstract, thoroughly interdisciplinary, and have the ability to span age divides. By focusing on a broader and more comprehensive definition of civic education in teacher education departments, this truly grassroots movement has untapped potential for the future of education, and the politics of social mobility and social justice in America today.

\section{REFERENCES}

Anderson, M. \& Auxier, B. (2020, 19 August). 55\% of U.S. social media users say they are 'worn out' by political posts and discussions. Pew Research Center.

https://www.pewresearch.org/fact-tank/2020/08/19/55-of-u-s-social-media-users-saythey-are-worn-out-by-political-posts-and-discussions/

Apple, M. (2013). Can Education Change Society? Routledge.

https://ebookcentral.proquest.com/lib/cofc/reader.action?docID=1075377

Bittman, B., \& Russell, W. (2016). Civic education in united states: A multiple regression of civic education scores from the national assessment of educational progress. Research in Social Sciences and Technology, 1(2).

Blessing, L. T., Chakrabarti, A. M., \& Wallace, K. M. (1998). An overview of descriptive studies in relation to a general design research methodology. In Designers (pp. 42-56). Springer, London.

Carr, P. (2008). Educating for Democracy: With or without Social Justice. Teacher Education Quarterly (Claremont, Calif.), 35(4), 117-136.

Center for Information and Research on Civic Learning and Engagement.(2013) All Together Now: Collaboration and Innovation for Youth Engagement: The Report of the Commission on Youth Voting and Civic Knowledge. (2013).

www.civicyouth.org/about-circle/ commission-on-youth-voting-civic-knowledge Center for Information and Research on Civic Learning and Engagement. (2017). A Study of Civic Education in Massachusetts. https://tischcollege.tufts.edu/research/study-civiceducation-massachusetts

Center for Information and Research on Civic Learning and Engagement. (2017). Teachers'

Views on Civic Education Summary of Research Findings. https://tischcollege.tufts.edu/research/study-civic-education-massachusetts

Center for Information and Research on Civic Learning and Engagement. (2018). 2018 Election 
Center. Retrieved from https://circle.tufts.edu/2018-election-center\#from-parkland-tothe-polls:-activism-and-voting

Center for Information and Research on Civic Learning and Engagement. (2018). Engaging a Broader Youth Electorate: 10 Recommendations for Increasing Voter Engagement. https://circle.tufts.edu/2018-election-center\#from-parkland-to-the-polls:-activism-andvoting

Center for Information and Research on Civic Learning and Engagement. (2018). Five

Takeaways on Social Media and the Youth Vote in 2018.

https://circle.tufts.edu/our-research/youth-media-democracy\#social-media-andpolitical-engagement

Center for Information and Research on Civic Learning and Engagement. (2020, March 21)/ Youth Make Up 1 in 9 South Carolina Voters. (2020, March 1)

https://circle.tufts.edu/latest-research/youth-make-1-9-south-carolina-voters

Center for Information and Research on Civic Learning and Engagement. Understanding Youth Attitudes and Beliefs in Civic Engagement and Youth Political Power.

http://circle.tufts.edu/our-research/understanding-youth-attitudes-and-beliefs\#beliefin-civic-engagement-and-youth-political-power

Counts, G. (1932/1978). Dare the School Build a New Social Order? Southern Illinois University.

Delpit, L. (1988). The Silenced Dialogue: Power and Pedagogy in Educating Other People's Children. Harvard Educational Review, 58(3), 280-299. https://doi.org/10.17763/haer.58.3.c43481778r528qw4

Delpit, L \& Perry, T. (1998). The Real Ebonics Debate: Power, Language, and the Education of African-American Children (Eds.). Boston, MA: Beacon Press.

Dunn, A. H., Sondel, B., \& Baggett, H. C. (2019). “I Don't Want to Come Off as Pushing an Agenda": How Contexts Shaped Teachers' Pedagogy in the Days After the 2016 U.S. Presidential Election. American Educational Research Journal, 56(2), 444-476. https://doi.org/10.3102/0002831218794892

Freire, P., \& Ramos, M. B. (1970/1992). Pedagogy of the oppressed. New York: Continuum. Flanagan, C., \& Levine, P. (2010). Civic Engagement and the Transition to Adulthood. The Future of Children 20(1), 159-179. doi:10.1353/foc.0.0043.

Hall, An'Drea E., "The Impact of Media Consumption on Civic Participation: Examining Media and Social Capital Effects" (2014). Research Papers. Paper 548.

Jansen, B. A. (2011). Civic education and the learning behaviors of youth in the online environment: A call for reform. Journal of Social Studies Education Research, 2(2), 22 42.

Johnson, B. (2001). Toward a new classification of nonexperimental quantitative research. Educational Researcher, 30(2), 3-13.

Kahne, J., \& Sporte, S. (2008). Developing Citizens: The Impact of Civic Learning 
Opportunities on Students' Commitment to Civic Participation. American Educational Research Journal,45(3), 738-766. doi:10.2307/27667149

Klein, Allison. (2017). Survey: Educators' Political Leanings, Who They Voted For, Where They Stand on Key Issues. https://www.edweek.org/ew/articles/2017/12/13/survey-paintspolitical-portrait-of-americas-k-12.html

Levine-Goldberg, J. (2009) Five Ways to Increase Civic Engagement. National Council for Social Studies. (22)1, 15-18.

https://www.socialstudies.org/system/files/publications/articles/yl_220115.pdf Matto, E., McCartney, A., Benninon, E., Simpson, D. (2017). Teaching Civic Engagement Across the Disciplines. American Political Science Association.

McCartney, A. (2011) Introduction. Teaching Civic Engagement Across the Disciplines. American Political Science Association.

Morrin, R. (2020). Coronavirus displaced millions of college students, who worry how they're going to vote. USA Today. April 21, 2020.

https://www.usatoday.com/story/news/politics/elections/2020/04/21/coronaviruscollege-students-worry-how-voting-affected/2945035001/

Lee, A. (2019, May 1). All Out SC teacher protest: 10,000 in 'largest gathering of teachers in history of SC.' Greenville News.

https://www.greenvilleonline.com/story/news/education/2019/05/01/all-out-scteacher-protest-rally-crowds-walkout/3632975002/

Milner, H. (2002). Civic literacy: How informed citizens make democracy work.

University Press of New England.

https://www.google.com/books/edition/Civic_Literacy/jOMuqXpMfuEC?hl=en\&gbpv=1 \&printsec=frontcover

Milner, R. (2017). Confronting Inequity / Reimagining the Null Curriculum. Educational Leadership. 75(3), 88-89. http://www.ascd.org/publications/educationalleadership/nov17/vol75/num03/Reimagining-the-Null\%20in\%20the\%20classroom.

Nieto, S. 2006. Teaching as Political Work: Learning from Caring and Courageous Teachers. The Longfellow Lecture.

Parker, K. Horowitz, J., Anderson, M. (2020). Amid Protests, Majorities Across Racial and Ethnic Groups Express Support for the Black Lives Matter Movement. Pew Research Center. Retrieved from https://www.pewsocialtrends.org/2020/06/12/amid-protestsmajorities-across-racial-and-ethnic-groups-express-support-for-the-black-lives-mattermovement.

Putnam, R. D. (1995). Tuning in, tuning out: the strange disappearance of social capital in America. PS: Political Science \& Politics, 28(4), 664+.

SC for Ed. Who We are. Scfor.ed.org. Retrieved from, https://www.scfored.org/who-we-are South Carolina Votes (2020). South Carolina voter registration demographics. 
https://www.scvotes.gov/cgi-bin/scsec/96vr?countykey=ALL\&D1=RACE

Southern Law and Poverty Center. (2016, November 28). The Trump Effect: The Impact of 2016 Election on Our Nation's Schools. SLPCenter.org.

https://www.splcenter.org/20161128/trump-effect-impact-2016-presidential-electionour-nations-schools

Syvertsen, A. K., Wray-Lake, L., Flanagan, C. A., Osgood, D. W., \& Briddell, L. (2011). Thirty Year Trends in U.S. Adolescents' Civic Engagement: A Story of Changing Participation and Educational Differences. Journal of Research on Adolescence : The Official Journal of the Society for Research on Adolescence, 21(3), 586-594.

https://doi.org/10.1111/j.1532-7795.2010.00706.x

Texas Media \& Society Survey: Topline Results 2018 (2018). University of Texas at Austin, Moody College of Communication.

Retrieved from https://moody.utexas.edu/sites/default/files/2018\%20Topline\%20Results.pdf Teachers' Views on Civic Education: Summary of Research Findings. Jonathan M. Tisch College of Civic Life. Tufts University. Retrieved from https://tischcollege.tufts.edu/research/study-civic-education-massachusetts Terrell, S. R. (2012). Mixed-methods research methodologies. Qualitative Report, 17(1), 254-280.

Thompson, B., Diamond, K. E., McWilliam, R., Snyder, P., \& Snyder, S. W. (2005). Evaluating the quality of evidence from correlational research for evidence-based practice. Exceptional Children, 71(2), 181-194.

Thorne, S., Kirkham, S. R., \& O'Flynn-Magee, K. (2004). The analytic challenge in interpretive description. International journal of qualitative methods, 3(1), 1-11.

Torney-Purta, J. (2002). The School's Role in Developing Civic Engagement: A Study of Adolescents in Twenty-Eight Countries. Applied Developmental Science, 6(4), 203-212. https://doi.org/10.1207/s1532480xads0604_7

Torney-Purta, J. Barber, H.C., Richardson, K.W. (2005) How Teachers' Preparation Relates to Students' Civic Knowledge and Engagement in the United States: Analysis from the IEA Civic Education Study. University of Maryland.

Torney-Purta, J. Richardson, K.W., Barber, H. C. (2004) Trust in Government-Related Institutions and Civic Engagement among Adolescents: Analysis of Five Countries from the IEA Civic Education Study. University of Maryland.

Trent, A. Cho, J. Rios, F. Mayfield, K. (2010). Democracy in Teacher Education: Learning from Preservice Teachers' Understandings and Perspectives. Woodring College of Education Faculty Publications. 18. https://cedar.wwu.edu/cgi/viewcontent.cgi?article=1017\&context=education_facpubs

Tyack, D., \& Cuban, L. (1995). Tinkering toward utopia : A century of public school reform. Harvard University Press. 
U.S Census Bureau (2017). Table 1: Reported Voting and Registration, by Sex and Single Years of Age.

November 2016. Retrieved From, https://www.census.gov/data/tables/timeseries/demo/voting-and-registration/p20-580.html

U.S. Census Bureau (2017). Table 2: Reported Voting and Registration, by Race, Hispanic Origin, Sex, and Age, for the United States: November 2016.

Retrieved from, https://www.census.gov/data/tables/time-series/demo/voting-and-registration/p20580.html

van Wagtendonk, A. (2020, March 1). Near-record turnout in South Carolina sets stage for Super Tuesday battles. Vox.https://www.vox.com/policy-and-

politics/2020/3/1/21159319/south-carolina-2020-democratic-primary-turnout-record Vesperman, D. and Caulfield, D. (2017) "Voting is Power!: Preservice Social Studies' Teachers' Conceptions of Democracy". Ohio Social Studies Review 54(1). Retrieved from file:///C:/Users/John/Downloads/2012-voting-is-power-preservice-social-studiesteachers-conceptions-of-democracy.pdf

Williams, C. (2007). Research methods. Journal of Business \& Economics Research (JBER), $5(3)$.

Wineberg, S. (2018). Why Learn History When It's Already on Your Phone? The University of Chicago Press.

Winkler, A. Schull, J. and Zeehandelaar, D.(2012) How Strong are Teacher Unions? A State-By-State Comparison. Thomas Fordham Institute. Retrieved from https://files.eric.ed.gov/fulltext/ED537563.pdf

Winthrop, R. (2020, June 4). The need for civic education in 21st-century schools. Brookings Institute. https://www.brookings.edu/policy2020/bigideas/the-need-for-civiceducation-in-21st-century-schools/ 